\title{
The Effectiveness of STP on Prevention of Iron Deficiency Anaemia among Primigrivida Mothers in Clinic of Selected Hospitals at Bellary
}

\author{
Ojas Omkar Samant ${ }^{1}$, A Mercyrani ${ }^{2}$ \\ Assistant Professor, Samarth Nursing College, Dervan, Ratnagiri District, Maharashtra \\ ${ }^{2}$ Professor, Indian College of Nursing, Bellary, Karnataka
}

\begin{abstract}
The Effectiveness of STP on Prevention Of Iron Deficiency Anaemia Among Primigravida Mothers In ANC Clinic of Selected Hospitals At Bellary." Background: Iron deficiency anemia is the most common micronutrient deficiency in the world today. It affects the lives of many millions of human beings through out their life cycle, especially women and infants. ${ }^{2}$ Nearly half of the global total number of anemic women live in the Indian sub-continent. In India alone, prevalence of anemia among pregnant women may be as high as $88 \%{ }^{3}$
\end{abstract}

Keywords: Prevention of Iron Deficiency Anaemia, Iron Deficiency Anaemia among Primigravida Mothers

\section{Introduction}

"Before You Were Born I Carried You Under My Heart".

(Mandy

Harrison)

The World Health Organization (WHO) has been concerned with the global problem of nutritional anemia for many years. The first FAO/WHO Joint committee On Nutrition, meeting held in 1949, discussed the importance of nutritional anemia and recommended that funds should be provided for its study, the first research in nutritional anemia was sponsored in 1955 and the first international meeting was called in 1958. The WHO still has an importance role to play in this field, encouraging the development of anemia control programs and providing advice and technical assistance to member of countries. ${ }^{1}$

Iron deficiency anemia is the most common micronutrient deficiency in the world today. It affects the lives of many millions of human beings through out their life cycle, especially women and infants. ${ }^{2}$

\section{Statement of the Problem}

"The effectiveness of STP on prevention of iron deficiency anemia among primigravida mothers in ANC clinic of selected hospitals at Bellary"

\section{Objectives}

1) To assess the knowledge on prevention of iron deficiency anaemia among primigravida mothers.

2) To develop and administer STP on prevention of iron deficiency anaemia a among primigravida mothers.

3) To compare the knowledge on iron deficiency anaemia of pre-test and post-test score among primigravida mothers.

4) To determine the association between post-test knowledge with selected demographic variables.

\section{Hypothesis}

H0 - There will be no significant difference between pre and post knowledge of primigravida mother on prevention of iron deficiency anaemia

H1 - There will be a significant difference between pre and post -test knowledge score among primigravida mothers on prevention of iron deficiency anaemia.

H2 - There will be a significant association between post test knowledge score of primigravida mothers regarding prevention of iron deficiency anaemia with selected demographic variable.

\section{Limitations}

1) The finding of the study could not be generalized in view of small sample size.

2) The findings of the study were limited to 50 primigravida mothers.

3) The attempt was not made to follow up, to measure the retention of knowledge after the Post-test. 
International Journal of Science and Research (IJSR)

ISSN (Online): 2319-7064

Index Copernicus Value (2015): 78.96 | Impact Factor (2015): 6.391
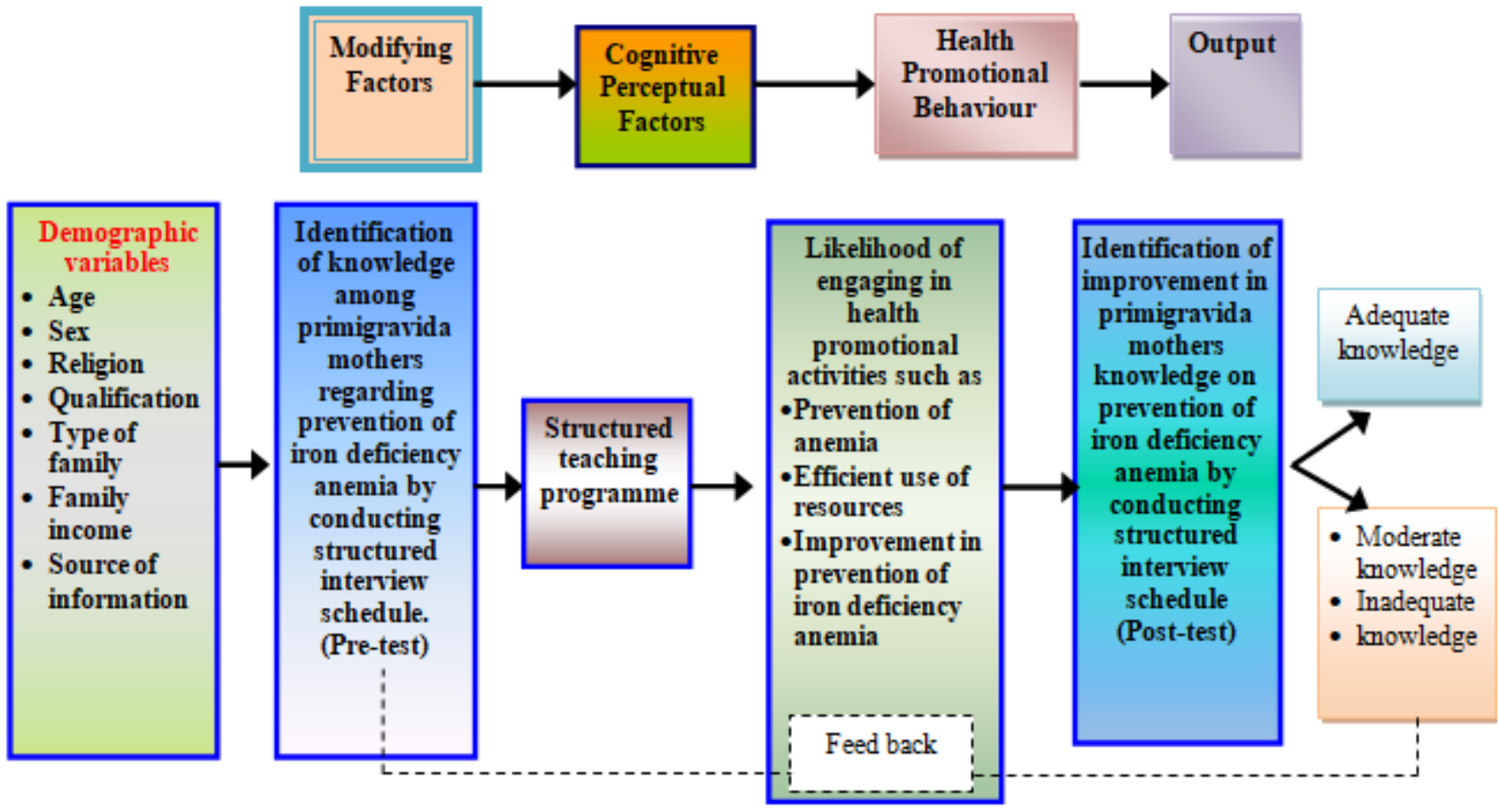

Figure 1: Conceptual Framework Based on Modified Pender's Health Promotion Model (1996)

\section{Materials and Methods}

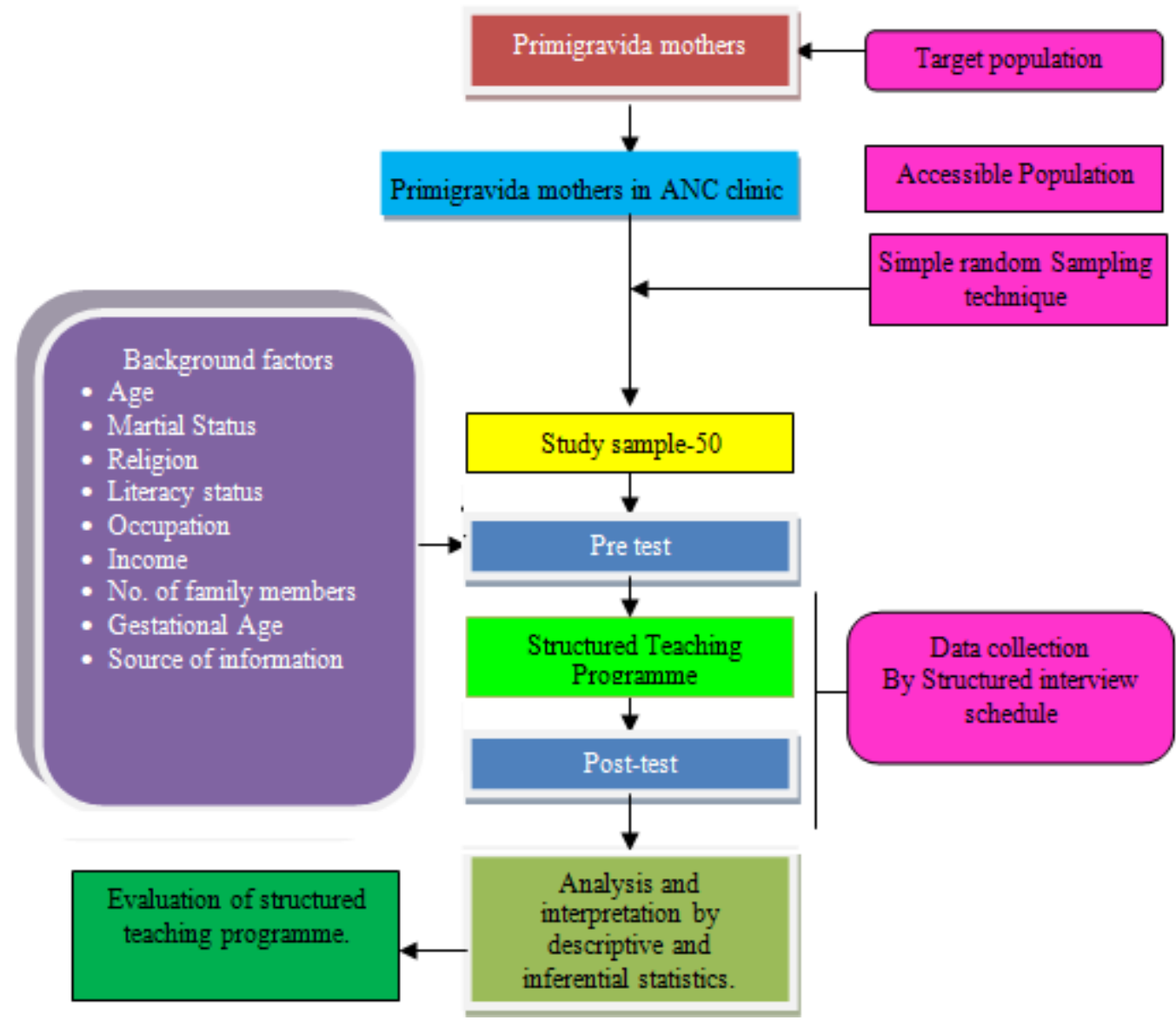

Volume 6 Issue 7, July 2017

www.ijsr.net 


\section{International Journal of Science and Research (IJSR)}

ISSN (Online): 2319-7064

Index Copernicus Value (2015): 78.96 | Impact Factor (2015): 6.391

\section{Findings}

Table 1: Classification of respondents based on pre-test level of knowledge

\begin{tabular}{|c|c|c|c|}
\hline S no & Pretest Level of knowledge & Frequency & Percentage \\
\hline 1 & Inadequate $(\leq 10)$ & 44 & 88 \\
\hline 2 & Average $(11-20)$ & 06 & 12 \\
\hline 3 & Adequate $(21-30)$ & 00 & 00 \\
\hline & Total & 50 & 100 \\
\hline
\end{tabular}

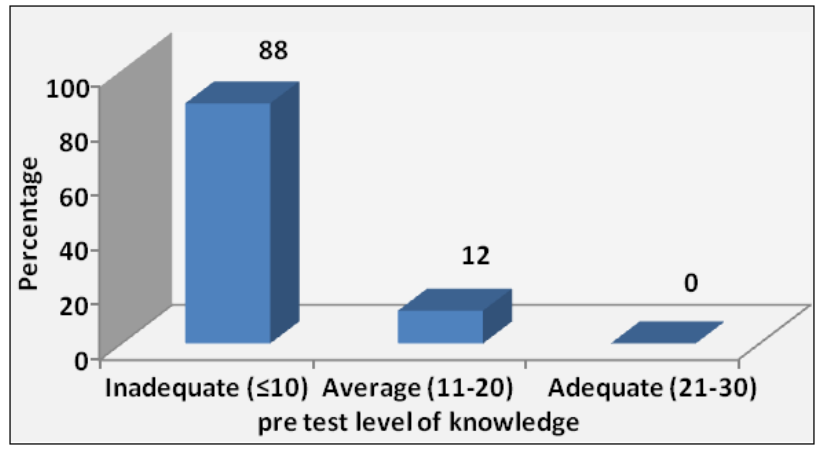

Figure 3: Bar digramme shows the classification of respondents based on Pre-test

\section{Level of Knowledge}

The above bar diagram shows that among 50 respondents; majority of subjects (88\%) had inadequate level of knowledge regarding iron deficiency anemia.

Section B: Findings related to post-test knowledge levels of primigravida mothers regarding iron deficiency anemia.

Table no 2: Mean, SD and mean percentage of pretest knowledge, $\mathrm{N}=50$

\begin{tabular}{|c|c|c|c|c|c|c|c|}
\hline No. & $\begin{array}{c}\text { Pretest } \\
\text { Knowledge }\end{array}$ & Statements & Min & $\begin{array}{c}\text { Max. } \\
\text { Score }\end{array}$ & Mean & SD & $\begin{array}{c}\text { Mean } \\
(\%)\end{array}$ \\
\hline $\begin{array}{c}\text { Pre-test } \\
\text { knowledge }\end{array}$ & 30 & 6 & 25 & 15.68 & 4.250 & 62.72 \\
\hline
\end{tabular}

The data in the table 2 shows the Post-test knowledge score of the subjects. The mean Post-test knowledge score of subjects was 15.68 with mean percentage of 62.72 .

Table 3: Classification of respondents based on post-test level of knowledge

\begin{tabular}{|c|c|c|c|}
\hline Sl no & Posttest Level of knowledge & Frequency & Percentage \\
\hline 1 & Inadequate $(\leq 10)$ & 06 & 12 \\
\hline 2 & Average $(11-20)$ & 36 & 72 \\
\hline 3 & Adequate $(21-30)$ & 08 & 16 \\
\hline & Total & 50 & 100 \\
\hline
\end{tabular}

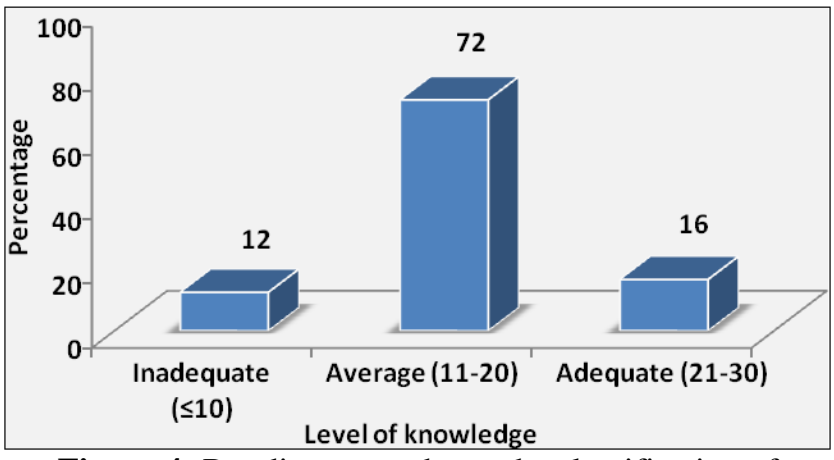

Figure 4: Bar digramme shows the classification of respondents based on Post-test Level of knowledge.

The above bar diagram shows that among 50 respondents; majority of subjects $(72.0 \%)$ had Average level of knowledge and $(16.0 \%)$ had adequate level of knowledge regarding iron deficiency anemia.

Section D: Findings related to effectiveness of STP on iron deficiency anemia.

Table 4: Association between pre-test and post-test knowledge scores, $\mathrm{N}=50$

\begin{tabular}{|c|c|c|c|c|c|c|c|c|}
\hline \multirow{2}{*}{ Aspects } & \multirow{2}{*}{$\begin{array}{c}\text { Max. } \\
\text { Score }\end{array}$} & \multicolumn{2}{|c|}{ Respondents Knowledge Scores } & Paired 't' & \multirow{2}{*}{ df } & \multirow{2}{*}{ P value } & \multirow{2}{*}{ Inference } \\
\cline { 3 - 5 } & Mean & SE of mean & Mean \% & Test & & & \\
\hline Post test & 30 & 15.68 & 4.250 & 52.26 & & & & \\
\hline Pre test & 30 & 7.96 & 2.762 & 26.53 & 20.600 & 49 & $<0.001$ & HS \\
\hline Enhancement & 30 & 7.720 & 0.375 & 25.73 & & & & \\
\hline
\end{tabular}

It is evident from the data presented in the table 6 that the calculated 't'value (20.60) was greater than the table value. Hence the research hypothesis was rejected at 0.05 level of significance. The mean difference between pre-test and posttest knowledge score was a true difference and not a chance difference. This indicates that the structured teaching programme was significantly effective in increasing the knowledge of primigravida mothers regarding iron deficiency anemia.

Table 5: Comparison between pre-test and post-test knowledge scores

\begin{tabular}{|c|c|c|c|}
\hline S no & Posttest Level of knowledge & $\begin{array}{c}\text { Pretest } \\
\text { percentage }\end{array}$ & $\begin{array}{c}\text { Post-test } \\
\text { Percentage }\end{array}$ \\
\hline 1 & Inadequate $(\leq 10)$ & 88 & 12 \\
\hline 2 & Average $(11-20)$ & 12 & 72 \\
\hline 3 & Adequate $(21-30)$ & 00 & 16 \\
\hline & Total & 100 & 100 \\
\hline
\end{tabular}

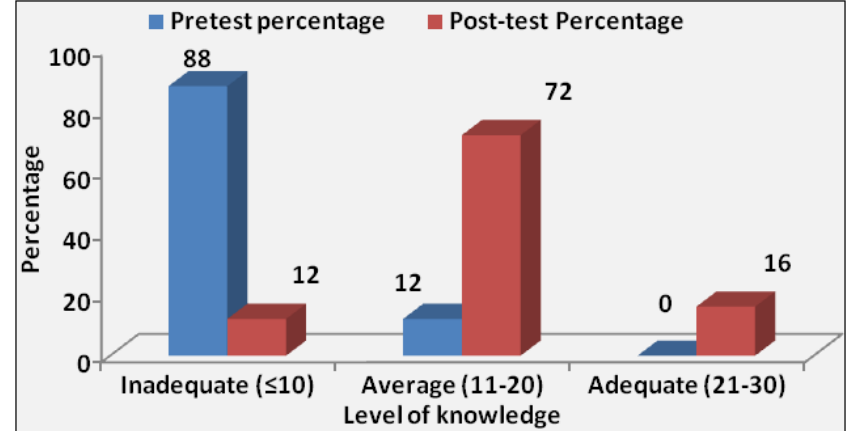

Figure 5: Bar digramme shows the comparison of Pre-test and Post-test Level of knowledge.

The above Bar digramme shows the comparison of Pre-test and Post-test level of knowledge. It is clear from the digramme that Most of the subjects $(72.0 \%)$ had average 


\section{International Journal of Science and Research (IJSR) \\ ISSN (Online): 2319-7064 \\ Index Copernicus Value (2015): 78.96 | Impact Factor (2015): 6.391}

Post-test knowledge whereas $(88.0 \%)$ subjects had Inadequate Pre-test knowledge regarding iron deficiency anemia.
Section D: Findings related to association between knowledge and selected demographic variables.

Table 6: Summary of association between pre test knowledge and demographic variables

$$
\mathrm{N}=50
$$

\begin{tabular}{|c|c|c|c|c|c|c|c|c|}
\hline S1 No & Demographic cl & racteristics & Below median & Median\& above & Ch-square value & $\mathrm{df}$ & P-value & Inference \\
\hline \multirow{3}{*}{1.} & \multirow{3}{*}{ Age } & $21-25$ & 12 & 23 & \multirow{3}{*}{2.126} & \multirow{3}{*}{2} & \multirow{3}{*}{0.345} & \multirow{3}{*}{ NS } \\
\hline & & $26-30$ & 4 & 10 & & & & \\
\hline & & $31-35$ & 1 & 0 & & & & \\
\hline \multirow{4}{*}{2.} & \multirow{4}{*}{ Religion } & Hindu & 10 & 20 & \multirow{4}{*}{5.003} & \multirow{4}{*}{3} & \multirow{4}{*}{0.172} & \multirow{4}{*}{ NS } \\
\hline & & Muslim & 1 & 8 & & & & \\
\hline & & Christian & 1 & 2 & & & & \\
\hline & & Others & 5 & 3 & & & & \\
\hline \multirow[t]{2}{*}{3.} & \multirow{2}{*}{ Type of family } & Nuclear & 11 & 21 & \multirow{2}{*}{0.006} & \multirow{2}{*}{1} & \multirow{2}{*}{0.941} & \multirow{2}{*}{ NS } \\
\hline & & Joint & 6 & 12 & & & & \\
\hline \multirow{4}{*}{4.} & \multirow{4}{*}{ Family income } & $>5000.00$ & 6 & 1 & \multirow{4}{*}{11.190} & \multirow{4}{*}{3} & \multirow{4}{*}{0.011} & \multirow{4}{*}{$\mathbf{S}$} \\
\hline & & $5001-10000$ & 7 & 20 & & & & \\
\hline & & $10001-15000$ & 4 & 8 & & & & \\
\hline & & $<15000$ & 0 & 4 & & & & \\
\hline \multirow[t]{2}{*}{5.} & \multirow{2}{*}{ Residence } & Urban & 11 & 22 & \multirow{2}{*}{0.019} & \multirow{2}{*}{1} & \multirow{2}{*}{0.890} & \multirow{2}{*}{ NS } \\
\hline & & Rural & 6 & 11 & & & & \\
\hline \multirow{5}{*}{6.} & & Illiterate & 3 & 1 & & & & \\
\hline & & Primary & 5 & 10 & & & & \\
\hline & Education & High school & 6 & 12 & 4.255 & 4 & 0.373 & NS \\
\hline & & PUC & 3 & 8 & & & & \\
\hline & & Degree/PG & 0 & 2 & & & & \\
\hline & & House wife & 7 & 21 & & & & \\
\hline 7. & Occunation & Govt & 7 & 9 & 3116 & 3 & 0.374 & NS \\
\hline & Uccupation & Private & 1 & 2 & 3.110 & 3 & $0.3 / 4$ & NS \\
\hline & & Buisiness & 2 & 1 & & & & \\
\hline 8. & Source of information & Yes & & & & -- & & \\
\hline & Source of intormation & No & 17 & 33 & & -- & & \\
\hline 1) & $\begin{array}{l}\chi_{(2)}^{2} \\
\chi_{(4)}^{2}\end{array}$ & $\begin{array}{l}.991, P<0.05 \\
.488, P<0.05\end{array}$ & & & & & & \\
\hline
\end{tabular}

NS: Not significant

The above table depicts the chi-square test value established at 0.05 level of significant for finding out the association between pre-test knowledge of primigravida mothers regarding iron deficiency anemia and selected demographic characteristics. The table denotes that calculated chi square values for all the variables was lesser than table value except for family income $\left(\mathrm{X}^{2}=11.190\right)$ at 0.05 level of significance.

Table 7: Summary of association between post test knowledge and demographic variables, $\mathrm{N}=50$

\begin{tabular}{|c|c|c|c|c|c|c|c|c|}
\hline Sl No & Demographic ch & tics & Below median & Median\& above & Ch-square value & $\mathrm{df}$ & P-value & Inference \\
\hline \multirow{3}{*}{1.} & \multirow{3}{*}{ Age } & $21-25$ & 15 & 20 & \multirow{3}{*}{1.403} & \multirow{3}{*}{2} & \multirow{3}{*}{0.496} & \multirow{3}{*}{ NS } \\
\hline & & $26-30$ & 7 & 7 & & & & \\
\hline & & $31-35$ & 1 & 0 & & & & \\
\hline \multirow{4}{*}{2.} & \multirow{4}{*}{ Religion } & Hindu & 15 & 15 & \multirow{4}{*}{1.020} & \multirow{4}{*}{3} & \multirow{4}{*}{0.796} & \multirow{4}{*}{ NS } \\
\hline & & Muslim & 3 & 6 & & & & \\
\hline & & Christian & 1 & 2 & & & & \\
\hline & & Others & 4 & 4 & & & & \\
\hline \multirow[t]{2}{*}{3.} & \multirow{2}{*}{ Type of family } & Nuclear & 17 & 15 & \multirow{2}{*}{1.817} & \multirow{2}{*}{1} & \multirow{2}{*}{0.178} & \multirow{2}{*}{ NS } \\
\hline & & Joint & 6 & 12 & & & & \\
\hline \multirow{4}{*}{4.} & \multirow{4}{*}{ Family income } & $>5000.00$ & 6 & 1 & \multirow{4}{*}{5.546} & \multirow{4}{*}{3} & \multirow{4}{*}{0.136} & \multirow{4}{*}{ NS } \\
\hline & & $5001-10000$ & 11 & 16 & & & & \\
\hline & & $10001-15000$ & 4 & 8 & & & & \\
\hline & & $<15000$ & 2 & 2 & & & & \\
\hline \multirow[t]{2}{*}{5.} & \multirow{2}{*}{ Residence } & Urban & 16 & 17 & \multirow{2}{*}{0.241} & \multirow{2}{*}{1} & \multirow{2}{*}{0.623} & \multirow{2}{*}{ NS } \\
\hline & & Rural & 7 & 10 & & & & \\
\hline \multirow{5}{*}{6.} & \multirow{5}{*}{ Education } & Illiterate & 4 & 0 & \multirow{5}{*}{6.282} & \multirow{5}{*}{4} & & \\
\hline & & Primary & 7 & 8 & & & & \\
\hline & & High school & 8 & 10 & & & 0.179 & NS \\
\hline & & PUC & 3 & 8 & & & & \\
\hline & & Degree/PG & 1 & 1 & & & & \\
\hline
\end{tabular}


International Journal of Science and Research (IJSR)

ISSN (Online): 2319-7064

Index Copernicus Value (2015): 78.96 | Impact Factor (2015): 6.391

\begin{tabular}{|c|c|c|c|c|c|c|c|c|}
\hline \multirow{4}{*}{7.} & \multirow{4}{*}{ Occupation } & House wife & 11 & 17 & \multirow{4}{*}{1.895} & \multirow{4}{*}{3} & \multirow{4}{*}{0.595} & \multirow{4}{*}{ NS } \\
\hline & & Govt & 9 & 7 & & & & \\
\hline & & Private & 1 & 2 & & & & \\
\hline & & Buisiness & 2 & 1 & & & & \\
\hline \multirow[t]{2}{*}{8.} & \multirow{2}{*}{ Source of information } & Yes & & & \multirow{2}{*}{-- } & & & \\
\hline & & No & 23 & 27 & & & & \\
\hline
\end{tabular}

$\chi_{(1)}^{2}=3.841, \mathrm{P}<0.05 \quad \chi_{(2)}^{2}=5.991, \mathrm{P}<0.05$

$\chi_{(3)}^{2}=7.815, \mathrm{P}<0.05 \quad \chi_{(4)}^{2}=9.488, \mathrm{P}<0.05$

NS: Not significant

The above table depicts the chi-square test value established at 0.05 level of significant for finding out the association between Post-test knowledge of primigravida mothers regarding iron deficiency anemia and selected demographic characteristics. The table denotes that calculated chi-square value for all the variables was lesser than table value. Hence it was concluded that there was no association found between post-test knowledge of primigravida mothers regarding iron deficiency anemia and selected demographic characteristics.

\section{Discussion}

This chapter has dealt with the analysis and interpretations of the result of the study. Both descriptive and inferential statistics were employed for the analysis of the data. The data analysis was carried out on the basis of objectives and hypothesis of study. Frequency and Percentage were used to analyze the demographic characteristics. The Paired ' $t$ ' test was used to find the effectiveness of structured teaching programme. The association of knowledge score with selected demographic variables was calculated using chisquare test.

\section{Conclusion}

This chapter deals with description of study findings, implication for nursing practice, nursing administration, nursing education and nursing research, limitation of the study and suggestions.

The following conclusions were drawn on the basis of the findings of the study.

1) The mean Pre-test knowledge score of subjects was 7.96 with mean percentage of 53.06.

2) The mean Post-test knowledge score of subjects was 15.68 with mean percentage of 62.72 .

3) The mean Post-test knowledge score was found to be significantly higher than mean Pre-test knowledge score at 0.05 level of significance $\left(\mathrm{t}_{49}=20.60 \mathrm{P}<0.05\right)$. Hence Structured teaching programme was found effective in increasing the knowledge of subjects on iron deficiency anemia.

4) The calculated chi square value for all the variables was lesser than table value except for family income $\left(\mathrm{X}^{2}=11.190\right)$ at 0.05 level of significance. Hence it was concluded that Pre-test knowledge score of primigravida mothers on iron deficiency anemia had only association with family income.

5) The calculated chi square value for all the variables was lesser than table value. Hence it was concluded that there was no association between post-test knowledge of primigravida mothers regarding iron deficiency anemia with selected demographic variables.

\section{Nursing Implications}

The finding of the study has valuable implications towards nursing education, nursing practice, nursing administration and nursing research.

\section{Nursing Education}

The nursing curriculum should incorporate activities like preparation of booklets, pamphlets, self teaching materials and video teaching programs. The curriculum should give importance to health education. The In-service education should be conducted to improve the knowledge and skills of health care professionals. Nursing students should be prepared to conduct health education programs. Hence nurses can conduct various health education programme to educate mothers on various topics such iron deficiency anemia.

\section{Nursing Practice}

Health education is an important tool of health care agency. It is one of the most cost-effective interventions. It is concerned with promoting health and welfare of family and society. The extended and expanded role of professional nursing emphasizes preventive and promotive aspects of health. Nurses are key person of a health team, who play a major role in the health promotion and its maintenance. It is a practicing profession, so the researcher's generally integrate findings into practice. Nurses working in hospital and community play an important role in giving health education particularly on iron deficiency anemia to primigravida mothers through different teaching methods.

\section{Nursing Administration}

Nursing administrators should implement out-reach programs to make the primigravida mothers, care-takers and public aware about iron deficiency anemia. The present study revealed that the primigravida mothers had poor knowledge regarding iron deficiency anemia. Special endeavors can be taken up by nursing administrator and educators to develop standards of care for primigravida mothers. The nursing administrator should organize in service education programme to nursing personnel and allied paramedical regarding iron deficiency anemia.

\section{Nursing Research}

Research essentially is problem-solving process. There is a wide scope of conducting research study in depth using different tools in order to assess the knowledge of 


\section{International Journal of Science and Research (IJSR) \\ ISSN (Online): 2319-7064}

Index Copernicus Value (2015): 78.96 | Impact Factor (2015): 6.391

primigravida mothers regarding iron deficiency anemia. Research studies can also be conducted on caretakers of primigravida mothers.

\section{Recommendations}

1) A similar study can be conducted on a larger sample for wider generalizations.

2) A study can be done to assess the knowledge of caregiver's of primigravida mothers on iron deficiency anemia. A similar study can be conducted in a different community to find out the significant difference between urban and rural community.

A comparative study can be conducted between two different teaching methods regarding knowledge of primigravida mothers on iron deficiency anemia

\section{References}

[1] Mother Care Matters, Anemia in pregnancy. Ruhsa department Vellore, Tamil nadu.1999; 234-43.

[2] UNICEF/WHO/UNUI, Technical Workshop "Preventing Iron deficiency in women and children". International Nutrition Foundations Canada, 1998.

[3] ICMR, Evaluation of the national nutritional anemia prophylaxis programme. Indian council of medical research, New Delhi. 1989.

[4] Watson and Williams, Folic acid deficiency in sicklecell anemia. East African Medical Journal. 1962; 39: 213221.

[5] Heinz Nutrition Foundation, In Torch Mumbai. 2001; 3:2. 7-9.6. Macgregor MW. Maternal anaemia as a factor in prematurity and perinatal mortality. Scottish Medical Journal, 1963, 8:134.

[6] Sohumann K. et al., Anemia Iron deficiency - Dietary adverse effects. Maximillans University, Munchen. 1998.

[7] Lops VR, Anemia in pregnancy. 1995; 51(5): 1189-97.

[8] Luigina DE Gasperi and Kung, Maltofer. International Inc in India Ferium. 1996; 1: 1-7.

[9] WHO, Preventing and controlling Iron deficiency anemia through primary health care. WHO Geniva, Switzerland. 1989.

[10] Health Action, Practical tips to combat nutritional anemia. 1994; 7(9): 11-12.

[11] CSSM Review, Anemia in preomancy, leading cause of maternal and perinatal mortality. 1993; 6:1-3. 